Magician of Sound 



\title{
Magician of Sound
}

Ravel and the Aesthetics of Illusion

\author{
Jessie Fillerup
}

甲

UNIVERSITY OF CALIFORNIA PRESS 
University of California Press

Oakland, California

(C) 2021 by Jessie Fillerup

Library of Congress Cataloging-in-Publication Data

Names: Fillerup, Jessie, 1976- author.

Title: Magician of sound : Ravel and the aesthetics of illusion / Jessie Fillerup.

Description: Oakland, California : University of California Press, [2021] | Includes bibliographical references and index.

Identifiers: LCCN 2020032179 (print) | LCCN 2020032180 (ebook) | ISBN 9780520379886 (cloth) | ISBN 9780520976962 (ebook)

Subjects: LCSH: Ravel, Maurice, 1875-1937-Criticism and interpretation. | Music and magic.

Classification: LCC ML410.R23 F55 2021 (print) | LCC ML410.R23 (ebook) | DDC $780.92[\mathrm{~B}]-\mathrm{dc} 23$

LC record available at https://lccn.loc.gov/2020032179

LC ebook record available at https://lccn.loc.gov/2020032180

Manufactured in the United States of America

$\begin{array}{lllllllll}29 & 28 & 27 & 26 & 25 & 24 & 23 & 22 & 21\end{array}$

$\begin{array}{llllllllll}10 & 9 & 8 & 7 & 6 & 5 & 4 & 3 & 2 & 1\end{array}$ 
For Michael and Rebecca, as ever 
